\title{
An Assessment of Aquifer Potential in and around a Proposed Well Field Area near Madunaghat, Chattogram Using Isotopic Techniques
}

\author{
Nasir Ahmed 1 , Manzoor Ahamad Choudhry ${ }^{2}$, Mohammed Khaliquzzaman ${ }^{3 *}$, Arif Ahamed ${ }^{3}$, \\ Mohammad Abdul Quaiyum Bhuiyan1, Nipa Deb1, Tasrina Rabia Choudhury4, \\ Mohammad Masud Karim', Sheikh Mohammad Mahbubur Rahman', \\ Mohammad Murshed Alam5, Abul Khair Mohammed Fazlullah', Mohammed Ariful Islam ${ }^{6}$ \\ ${ }^{1}$ Isotope Hydrology Division, Institute of Nuclear Science and Technology, Bangladesh Atomic Energy Commission, Dhaka, \\ Bangladesh \\ ${ }^{2}$ Isotope Hydrology Section, International Atomic Energy Agency, Vienna, Austria \\ ${ }^{3}$ The World Bank, Dhaka, Bangladesh \\ ${ }^{4}$ Chemistry Division, Atomic Energy Centre, Dhaka, Bangladesh \\ ${ }^{5}$ Institute of Water Modelling, Dhaka, Bangladesh \\ ${ }^{6}$ Chattogram Water Supply and Sewerage Authority, Chattogram, Bangladesh \\ Email: *dkhaliquzzaman@worldbank.org
}

How to cite this paper: Ahmed, N., Choudhry, M.A., Khaliquzzaman, M., Ahamed, A., Bhuiyan, M.A.Q., Deb, N., Choudhury, T.R., Karim, M.M., Rahman, S.M.M., Alam, M.M., Fazlullah, A.K.M. and Islam, M.A. (2021) An Assessment of Aquifer Potential in and around a Proposed Well Field Area near Madunaghat, Chattogram Using Isotopic Techniques. Journal of Water Resource and Protection, 13, 395-418.

https://doi.org/10.4236/jwarp.2021.136024

Received: April 21, 2021

Accepted: June 12, 2021

Published: June 15, 2021

Copyright $\odot 2021$ by author(s) and Scientific Research Publishing Inc. This work is licensed under the Creative Commons Attribution International License (CC BY 4.0).

http://creativecommons.org/licenses/by/4.0/

\begin{abstract}
The study was undertaken for understanding the potential of deep aquifers as a source of safe drinking water and for assessing the status of groundwater aquifer near Madunaghat area, Chattogram. The specific issues are salinity, interconnectivity of the shallow and deep aquifers, mixing of groundwater with the adjacent Halda river water, recharge condition and groundwater age. The isotopic data suggest that most of the groundwater results from a mixture between recent recharge and an older component recharge under climatic conditions cooler than at present. The interconnectivity between shallow aquifers and river waters are mostly found in the line wells installed particularly in shallow depth $(16 \mathrm{~m})$ close to Halda river as evidenced from the similar tritium values of sampled line well water with that of the Halda river water. The groundwater in Madunaghat well field area is not affected by salinity, as it is evidenced by higher values of $\mathrm{Na} / \mathrm{Cl}$ ratio of the groundwater samples compared to the sea water fresh water mixing line. The geochemistry of intermediate and deep groundwater is dominated by $\mathrm{Na}-\mathrm{Mg}-\mathrm{HCO}_{3}$ and $\mathrm{Na}-\mathrm{HCO}_{3}$ type waters. Even the relationship between chloride and oxygen-18 $\left(\mathrm{Cl}-\delta^{18} \mathrm{O}\right)$ depicts that the waters from the deep, intermediate and shallow
\end{abstract}


wells do not fall on the seawater mixing line. The Carbon-14 contents of intermediate to deep groundwater samples vary from 16.2 to $59.3 \mathrm{pMC}$ indicating the residence time in the range of 4300 to 15,000 years BP, i.e., the sourced water recharged the aquifers a long time ago. The intermediate and deep wells have water with arsenic concentrations less than the detection limit of $3.0 \mu \mathrm{g} / \mathrm{L}$. Only a few shallow wells have arsenic concentrations greater than the detection limit varying from $13.7-47.4 \mu \mathrm{g} / \mathrm{L}$, which is less than the DoE permissible limit $(50 \mu \mathrm{g} / \mathrm{L})$ implying that the groundwater at Madunaghat area is not affected by Arsenic contamination.

\section{Keywords}

Stable Isotope, Tritium, Carbon-14, Salinity, Chloride, Recharge,

Residence Time

\section{Introduction}

Chattogram is the second largest city and the main sea port of Bangladesh. The total area of Chattogram and sub-urban areas (including proposed Hathazari and Sitakunda) is around $550 \mathrm{~km}^{2}$ [1]. It is an industrial city which is growing rapidly and the population of the City Corporation area is currently estimated to be about 3.8 million [2]. At present the demand for water supply within the city area is about 600 million liters per day (MLD). Chattogram Water Supply and Sewerage Authority (CWASA) have been supplying about 210 MLD for a long time. Out of the 210 MLD production, 91 MLD production is from the Mohra Water Treatment Plant and the rest is from abstracted groundwater being treated through an iron removal plant at Kalurghat (68 MLD capacity) augmented by a few local supply deep wells (60 MLD). Recently, two new plants Modunaghat (100 MLD) and Karnaphuli (136 MLD) have been added. As reported by Rahman et al. [3], the shortfall in water supply which was $50 \%$ earlier, has decreased substantially. Despite the abundance of groundwater resources, there is a considerable shortage of treated water supply to the city; as groundwater has high iron (Fe) and total dissolved solids (TDS).

The city is situated within a cavity of surface water source from Bay of Bengal, Karnaphuli River and Halda River (a tributary of Karnaphuli) [4]. CWASA has recently completed construction of a water treatment plant (WTP) at Madunaghat with a capacity of 90 MLD treated water. However, during the dry season (i.e. November to May), the salinity of Halda river water sometimes (i.e. a number of weeks per year) crosses the $500 \mathrm{ppm}$ limit which is usually considered the typical limit for drinking water. This period is likely to increase in the future (i.e. within the lifetime of WTP) due to combined impact of lower river flow, climate change and sea level rise. It may, therefore, be necessary to augment the water intake from Halda with lower salinity water for the WTP during high salinity periods to maintain the salinity within the prescribed limits. Having considered 
the various options for this, the augmentation with low salinity groundwater has been identified as viable approach; if sustainable low salinity groundwater supply is available. Subsequently, CWASA had decided to investigate the potentials of groundwater in the deeper depth and the sustainability of groundwater aquifer system near the Madunaghat WTP with an aim to study the possibility of using groundwater to augment the water intake of Madunaghat WTP; to lower the salinity level of raw water from Halda river during high salinity periods to maintain the salinity of finished water within the prescribed limit.

During the last two decades, a few research groups studied the groundwater dynamics and hydrogeochemistry in the coastal areas of the Bengal basin using a variety of techniques. These have included environmental stable and radioactive isotopic studies to determine the groundwater recharge, provenance of groundwater, salinization process, interconnectivity, and residence times of shallow and deep aquifers [5] [6] [7] [8] [9]. However, no previous basin-scale isotopic study has been done in eastern part of coastal area of Bangladesh. Systematic environmental isotopic (stable isotope $\delta^{2} \mathrm{H}, \delta^{18} \mathrm{O} \& \delta^{13} \mathrm{C}$, and radioactive isotope ${ }^{3} \mathrm{H}$ $\&{ }^{14} \mathrm{C}$ ) and geochemical studies were carried out in and around the proposed well field area at Madunaghat, Chattogram; to understand the groundwater flow system, sources of aquifer recharge and possible hydraulic interconnection between aquifers and surface waters, and also to identify the aquifers with acceptable concentrations of salinity.

\section{Description of Study Area}

\subsection{Study Area and Climate}

The study area in Chattogram is located at the south eastern part of Bangladesh (Figure 1). Its importance as a port and trading center goes back to the $9^{\text {th }}$ century. The study area covers almost $15 \mathrm{sq} / \mathrm{km}$. This area has been proposed for well field construction because the area located in a synclinal flat area that are guided by two long hill ranges. This situation is likely to support accumulation of rainfall and facilitate higher rate of aquifer recharge.

The Chattogram region lies in the path of heavily moisture-laden monsoon winds. The rainy season extends from June through September and about $80 \%$ of the annual rainfall in concentrated in this season. The average annual rainfall in the area is found to vary between $2200-3600 \mathrm{~mm}$. The hot spell continues from April to July and means monthly temperature ranges from $30^{\circ} \mathrm{C}$ to $40^{\circ} \mathrm{C}$. Minimum recorded temperature ranges from $8.9^{\circ} \mathrm{C}$ to $12.8^{\circ} \mathrm{C}$. Although the humidity is $35 \%$ - $45 \%$ from November through March, it becomes $80 \%$ or even higher during the rainy season. Wind is generally considered to be mild except during strong thunderstorms and cyclones. The maximum wind velocity recorded is $60 \mathrm{~m} / \mathrm{s}$. Such winds occur generally in May through October.

\subsection{Geology and Hydrogeology}

Geomorphologically Chattogram city lies in the southern part of the Sitakund 


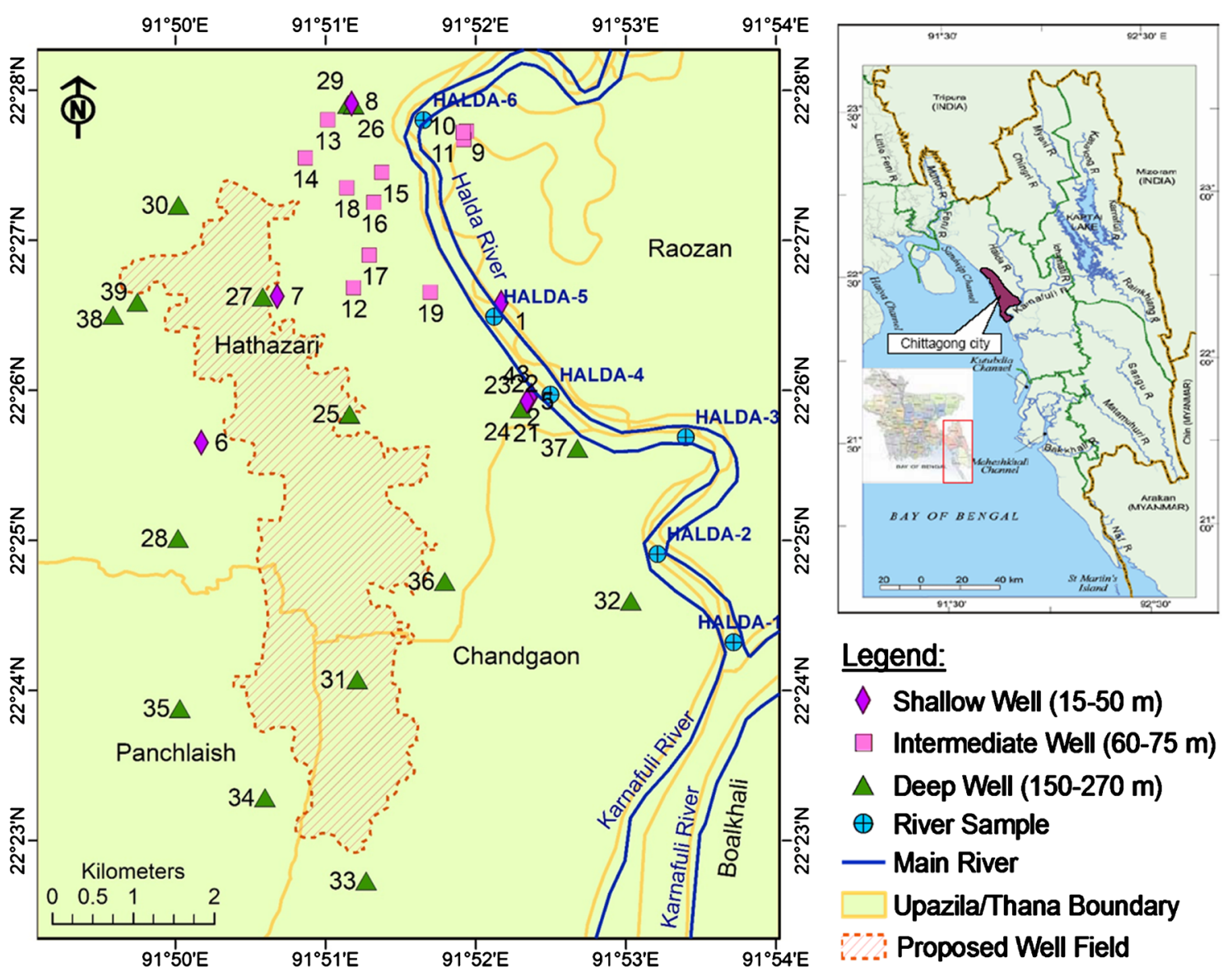

Figure 1. Location map of Chattogram City and surrounding areas with sampling points of groundwater and Halda river water near Madunaghat area.

anticline that is surrounded by the floodplain of the Halda River, tidal plain of the Karnafuli River and Bay of Bengal to the extreme west (Figure 1). The hill range is characterized by numerous ridges and valleys. The flood plain and tidal flats have low flat topography and sloping towards the sea. From the physiographical consideration, the investigated area may be divided into three distinct physiographic units, namely, the western flat alluvial coastal belt, the central tertiary hills and the eastern Halda flood plain. The study area lies mostly in western part of the western quite zone and belongs to the southernmost extension part of the Sitakund anticline. Surface geology of the study area has two distinct patterns. Quaternary sediments are exposed in the southern part of the study area in between Karnaphuli River in the east and south, and Bay of Bengal in the west. Tertiary sediments are mainly exposed in the northern part of the study area with piedmont and valley fill deposits that cover the surface at western and eastern side of the northern half [10] [11]. Hydrogeology of the study area is tectonically and structurally controlled. Aquifers in the study area are formed mostly by Quaternary alluvial sands. The subsurface geological cross-sections along A-A', B-B' and C-C' (Figure 2) directions have been prepared using the exploratory borehole data and borelogs of production wells. The top layer of the 

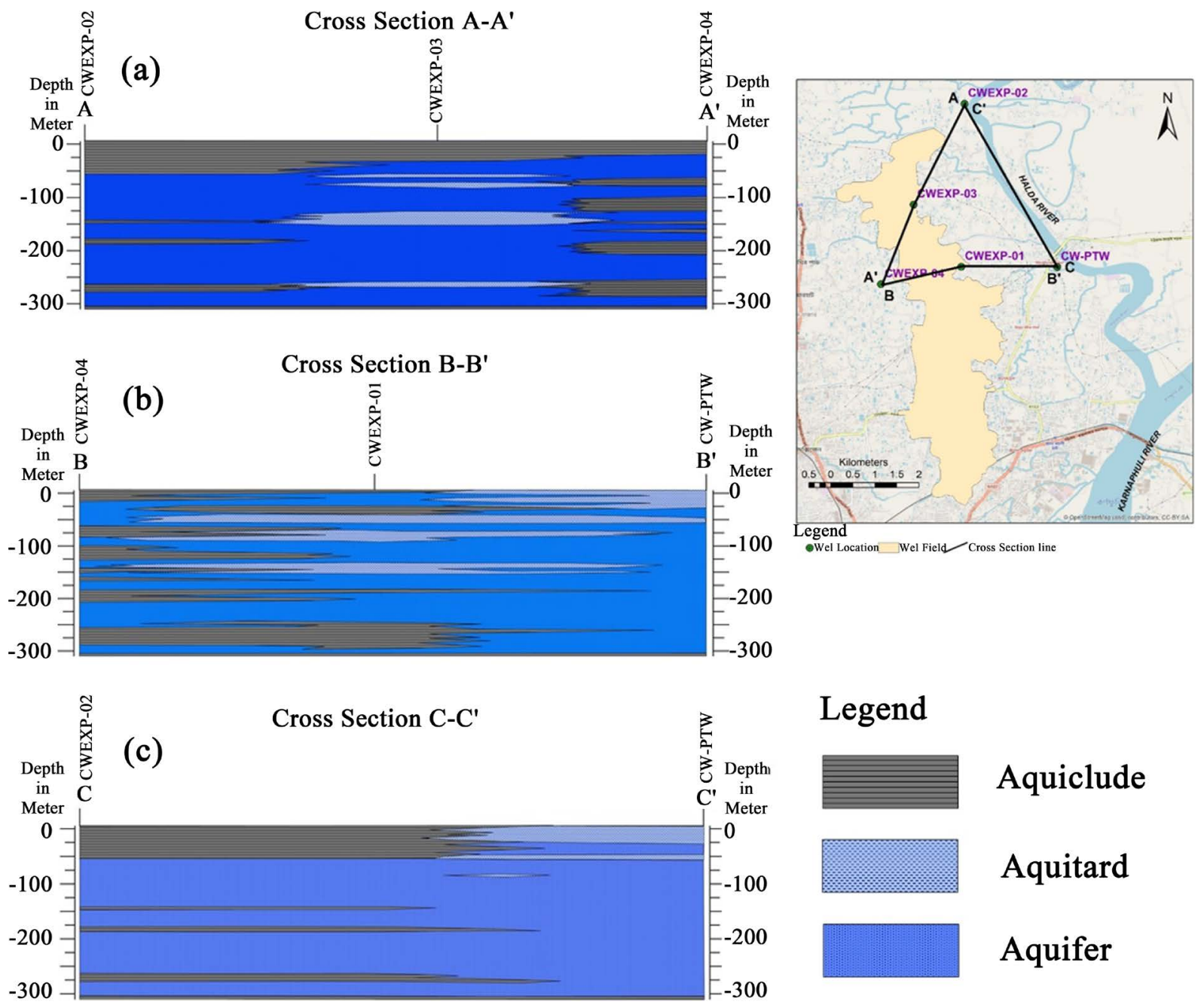

Legend

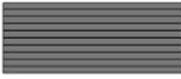

Aquiclude

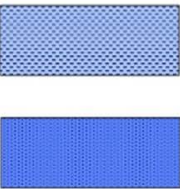

Aquitard

Aquifer

Figure 2. Subsurface geological cross-section on and around well field area, Madunaghat along line A-A', B-B' and C-C'.

section is composed of grey to brown clay with thickness varying from $20-50$ $\mathrm{m}$. Then fine to medium sand with gravel layer is underlain by the upper clay unit and this layer extends up to the depth of $300 \mathrm{~m}$. Medium to coarse sand layer with gravel bed is found at greater depth interbedded with clay lenses. This is the most prospective water-bearing zone. The aquifer of the study area is semi-confined. Similar type of aquifer system is found by [12] at the BWDB office compound, Bohaddarhat, Chattogram City. Human intervention and sea salinity are the major threat to aquifer vulnerability.

\section{Materials and Methods}

\subsection{Hydrochemical and Isotopic Sampling}

The sampling strategy was followed by making $5 \mathrm{~km} \times 5 \mathrm{~km}$ grid in the topo map of the Madunaghat well field area [13]. The whole map was divided into two transects; east-west and north-south. The lengths covered for sample collection in east-west and north-south direction are approximately $6 \mathrm{~km}$ and $11 \mathrm{~km}$ respectively. A total of 39 groundwater samples were collected from different 
categories of wells, such as, line wells of shallow depth, deep monitoring wells, CWASA production wells, deep wells installed by Department of Public Health Engineering (DPHE) and local shallow hand tubewells in and around the study area. Six surface water samples were collected from upstream to downstream of Halda River. Sampling locations are portrayed in a topographic map as displayed in Figure 1. Purging was first carried out on all wells prior to groundwater sampling [14]. As most of the surveyed wells are regularly used for drinking and other purposes, the well purging was done for shorter period i.e. 40 - 60 minutes using submersible pump and peristaltic pump. The geographical locations (latitude and longitude) of the wells were determined with a global positioning system (GPS) machine.

On-site measurement of physico-chemical properties (such as $\mathrm{pH}, \mathrm{EC}$, Temp. and DO) of water samples was done using an in-line flow-cell. Alkalinity $\left(\mathrm{HCO}_{3}^{-}\right)$was determined on-site by point inflection method using Digital Titrator of HACH International, USA. Sampling for chemical and isotope analysis were filtered using $0.45 \mu \mathrm{m}$ cellulose acetate membrane filter paper using an in-line filtration unit following the USGS protocol [13]. The water samples for anion $\left(\mathrm{Cl}^{-}, \mathrm{NO}_{3}^{-}\right.$and $\left.\mathrm{SO}_{4}^{2-}\right)$ analysis were collected in $500 \mathrm{~mL}$ polyethylene bottles with filtered and unacidified (FU) condition. Samples collected in 250 $\mathrm{mL}$ polyethylene bottles for cations $\left(\mathrm{Na}^{+}, \mathrm{K}^{+}, \mathrm{Ca}^{2+}\right.$ and $\left.\mathrm{Mg}^{2+}\right)$ and other trace elements ( $\mathrm{Fe}$ and $\mathrm{Mn}$ ) including Arsenic (As) analysis were filtered and acidified (FA) using concentrated analytical-grade $\mathrm{HNO}_{3}$ to reach a $\mathrm{pH}<2$ for preventing absorption and chemical precipitation. The wells are categorized in three group with respect to depth, namely, shallow well (15 - $50 \mathrm{~m}$ depth), intermediate well (60 - $75 \mathrm{~m}$ depth) and deep well (150 - $270 \mathrm{~m}$ depth). As the river water contains huge amount of suspended sediment particles and other impurities, the samples collected for hydro-chemical and isotope analysis were filtered using the capsule filters having $0.45 \mu \mathrm{m}$ pore size. Water samples for stable isotope $\left(\delta^{18} \mathrm{O}\right.$ and $\left.\delta^{2} \mathrm{H}\right)$ and tritium $\left({ }^{3} \mathrm{H}\right)$ analysis were filtered $(0.45 \mu \mathrm{m})$ into a $50 \mathrm{~mL}$ and $500 \mathrm{~mL}$ in a pre-cleaned, leak tight double stoppered high density polyethylene (HDPE) bottles respectively. Samples for ${ }^{13} \mathrm{C} /{ }^{12} \mathrm{C}$ and ${ }^{14} \mathrm{C}$ activity determination were filtered and collected in a $1000 \mathrm{~mL}$ HDPE plastic bottles and were sterilized for conservation by adding 50 drops of $\mathrm{I}_{2}-\mathrm{KI}$ solution per 1 liter sample.

\subsection{Laboratory Analysis}

The major anions $\left(\mathrm{Cl}^{-}, \mathrm{NO}_{3}^{-}\right.$and $\left.\mathrm{SO}_{4}^{2-}\right)$ of filtered water samples were analyzed by an Ion Chromatograph. The major cations $\left(\mathrm{Na}^{+}, \mathrm{K}^{+}, \mathrm{Ca}^{2+}\right.$ and $\left.\mathrm{Mg}^{2+}\right)$ and trace elements ( $\mathrm{Fe}$ and $\mathrm{Mn}$ ) of filtered and acidified samples were analyzed by Atomic Absorption Spectrometer (AAS). The arsenic was measured in AAS using hydride generation technique. The relative standard deviation for all the samples was within $\pm 5 \%$. The hydro-chemical analyses were performed in the Isotope Hydrology Laboratory, Institute of Nuclear Science \& Technology, Atomic Energy Research Establishment, Savar, Dhaka and in the Analytical 
Chemistry Laboratory, Atomic Energy Centre, Dhaka. The stable isotope $\left(\delta^{2} \mathrm{H}\right.$ and $\delta^{18} \mathrm{O}$ ) of precipitation and groundwater samples were analyzed in the Division of Isotope Application, PINSTECH, Pakistan using Isotope Ratio Mass Spectrometer. Tritium determinations were performed in Hydrosys Labor Analytical Laboratory Ltd., Budapest, Hungary using a Low Level Liquid Scintillation Counter after electrolytic enrichment. Radiocarbon activity and $\delta^{13} \mathrm{C}$ were analyzed in the laboratory of University of Groningen, the Netherlands by Accelerator Mass Spectrometry.

\section{Results and Discussion}

\subsection{Physical Parameters}

\subsubsection{Dissolved Oxygen}

In general, groundwater in the deltaic region is suboxic to anoxic (i.e. $<1 \mathrm{mg}$ $\mathrm{O}_{2} \cdot \mathrm{L}^{-1}$ ), as revealed by low dissolved oxygen (DO) measurements, high dissolved $\mathrm{Fe}$ concentrations, and copious amounts of $\mathrm{Fe}$ oxides precipitates in unflushed piezometers. Pollution by sewage and other organic compounds results in consumption of the DO [15]. The groundwaters at Madunaghat area display a large range $(0.0-13.9 \mathrm{mg} / \mathrm{L})$ of $\mathrm{DO}$ values. The measured $\mathrm{DO}$ of groundwater at shallow, intermediate and deep wells varies from 0.08 to $0.71 \mathrm{mg} / \mathrm{L}, 0.00$ to 0.98 $\mathrm{mg} / \mathrm{L}$ and 0.00 to $0.1 \mathrm{mg} / \mathrm{L}$ respectively with some exception in four deep production wells of CWASA as explained below. The average DO values in groundwater of these three types wells are $0.36,0.32$ and $0.02 \mathrm{mg} / \mathrm{L}$, respectively. DO content is typically low in deep aquifers, or even in shallow aquifers, particularly if the aquifer contains organic matter. But the DO values of four CWASA production wells except one at Anannaya (DTW-38) are excessively high (ranging from $6.8 \mathrm{mg} / \mathrm{L}$ to $13.9 \mathrm{mg} / \mathrm{L}$ ) (Figure 3); which are artefacts due to swirling of water through the borehole and sampling cell. The use of high capacity submersible or turbine pump in the CWASA production wells might have caused aeration which can artificially raise the DO levels. Groundwater production

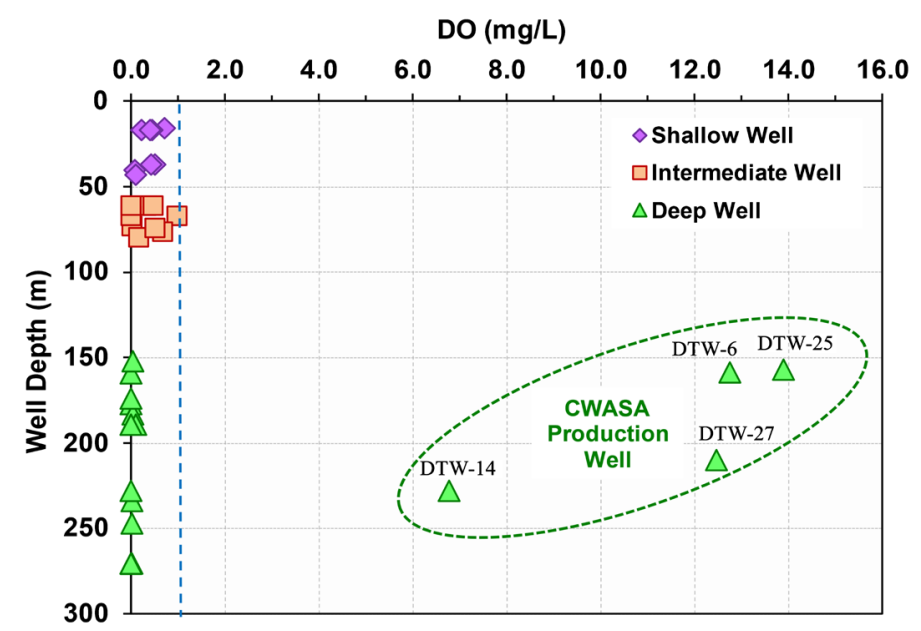

Figure 3. Concentration profile of DO with respect to different types of well. The CWASA deep production wells within the ellipse show high DO values. 
from large diameter wells can potentially introduce DO into the aquifer and the sample by entraining air within the cone of depression. Another major problem with sampling from production wells involves mixing groundwater from different stratigraphic horizons. Moreover, the DO is a vital water quality parameter in rivers as it determines the diversity of aquatic life that can be supported there. The DO of Halda river water varies from 5.86 to $6.42 \mathrm{mg} / \mathrm{L}$. The river in the studied area has DO greater than $4.0 \mathrm{mg} / \mathrm{L}$ [16] indicating sufficient DO levels to support most forms of aquatic life.

\subsubsection{Electrical Conductivity}

The electrical conductivity (EC) of most of groundwater samples lies in the range of drinking water standards adapted in Bangladesh. For groundwater, EC values less than $500 \mu \mathrm{S} / \mathrm{cm}$ is suitable for drinking purposes, whereas greater than $500 \mu \mathrm{S} / \mathrm{cm}$ may indicate the water to be polluted. The EC of shallow aquifer varies from 200 to $756 \mu \mathrm{S} / \mathrm{cm}$ with an average of $454 \mu \mathrm{S} / \mathrm{cm}$. On the other hand, the EC of intermediate aquifer varies from 194 to $545 \mu \mathrm{S} / \mathrm{cm}$ with an average of $283 \mu \mathrm{S} / \mathrm{cm}$. The lowest values of EC are observed in the deep aquifer system and it varies from $170-303 \mu \mathrm{S} / \mathrm{cm}$ with an average of $222 \mu \mathrm{S} / \mathrm{cm}$. This high variation in EC may possibly be attributed to localized effects from secondary recharge of water with a lower EC. Figure 4 shows distribution of EC at different depths of groundwater in the study area. The average EC of six Halda river samples taken at different points during high tide was found $127 \mu \mathrm{S} / \mathrm{cm}$. The backwater effect from the Karnaphuli estuary did not influence the salinity level in the Halda river during sampling time. This might have happened as the discharge in the outfall river Karnaphuli was observed full during high tide.

\subsection{Major Anions and Cations}

The descriptive statistics of field and analytical parameters are depicted in Table 1. The relative tendency of ions in $\mathrm{mg} / \mathrm{L}$ shows $\mathrm{Na}>\mathrm{Mg}>\mathrm{Ca}>\mathrm{K}$ and $\mathrm{HCO}_{3}>$ $\mathrm{Cl}>\mathrm{SO}_{4}$. The maximum permissible limit of Department of Environment (DoE)

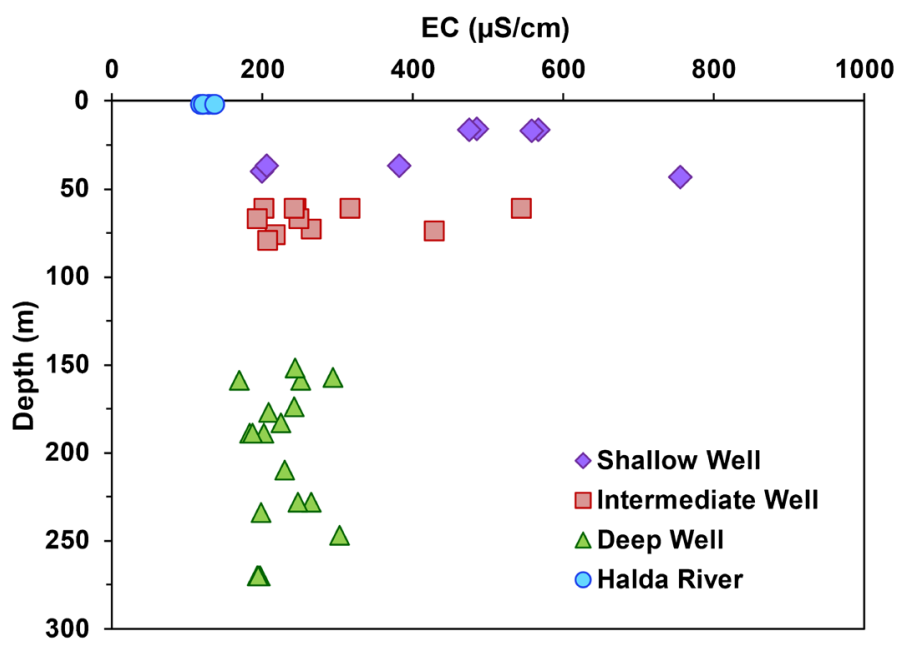

Figure 4. Variation of electrical conductivity (EC) at different depths of the aquifer system. 
Table 1. Descriptive statistical summary for the physical and chemical parameters of groundwater and river water samples. (Minimum [Min], Maximum [Max], Average [Avg], Median [Med], Standard Deviation [SD]). The units of DO, anions, cations and trace elements are $\mathrm{mg} / \mathrm{L}$. The concentration of As is given as $\mu \mathrm{g} / \mathrm{L}$.

\begin{tabular}{|c|c|c|c|c|c|c|c|c|c|c|c|c|c|c|c|c|c|}
\hline \multicolumn{2}{|c|}{ Attributes } & $\begin{array}{l}\text { Well } \\
\text { Depth }\end{array}$ & $\mathrm{pH}$ & $\begin{array}{l}\text { Temp } \\
\left({ }^{\circ} \mathrm{C}\right)\end{array}$ & EC & DO & $\mathrm{Cl}$ & $\mathrm{NO}_{3}$ & $\mathrm{SO}_{4}$ & $\mathrm{HCO}_{3}$ & $\mathrm{Na}$ & $\mathrm{K}$ & $\mathrm{Ca}$ & $\mathrm{Mg}$ & $\mathrm{Fe}$ & Mn & As \\
\hline \multirow{5}{*}{$\begin{array}{l}\text { Shallow Well } \\
\qquad \mathrm{n}=8\end{array}$} & Min & 16 & 5.63 & 25.9 & 200 & 0.08 & 2.06 & 0.66 & 0.06 & 118 & 25.6 & 1.24 & 5.02 & 4.88 & 0.30 & 0.02 & 3.0 \\
\hline & Max & 43 & 6.68 & 28.2 & 756 & 0.71 & 94.8 & 17.3 & 16.2 & 299 & 85.5 & 8.92 & 18.8 & 32.9 & 12.3 & 1.46 & 47.4 \\
\hline & Avg & 28 & 6.16 & 27.0 & 454 & 0.36 & 22.1 & 4.66 & 6.43 & 217 & 40.4 & 3.63 & 13.0 & 17.9 & 7.31 & 0.55 & 16.9 \\
\hline & Med & 27 & 6.14 & 27.0 & 481 & 0.42 & 14.0 & 2.61 & 2.33 & 231 & 36.3 & 2.70 & 13.4 & 17.6 & 8.13 & 0.30 & 8.3 \\
\hline & SD & 12 & 0.30 & 0.90 & 176 & 0.20 & 28.4 & 5.32 & 6.53 & 58 & 17.8 & 2.30 & 4.12 & 10.3 & 4.65 & 0.54 & 16.8 \\
\hline \multirow{5}{*}{$\begin{array}{l}\text { Intermediate } \\
\text { Well } n=11\end{array}$} & Min & 61 & 5.44 & 25.9 & 194 & 0.00 & 2.07 & 0.27 & 0.21 & 58 & 17.8 & 1.34 & 2.96 & 4.16 & 0.08 & 0.01 & 3.0 \\
\hline & Max & 79 & 6.34 & 27.5 & 545 & 0.98 & 18.3 & 19.6 & 3.01 & 234 & 67.9 & 13.2 & 5.16 & 16.2 & 15.5 & 0.38 & 4.9 \\
\hline & Avg & 67 & 5.85 & 26.4 & 283 & 0.32 & 8.78 & 5.67 & 1.12 & 129 & 35.0 & 4.16 & 4.05 & 7.33 & 6.35 & 0.26 & 3.2 \\
\hline & Med & 67 & 5.84 & 26.3 & 245 & 0.32 & 8.02 & 2.90 & 0.71 & 154 & 31.4 & 3.38 & 4.00 & 7.24 & 7.14 & 0.28 & 3.0 \\
\hline & SD & 7 & 0.31 & 0.50 & 105 & 0.31 & 5.67 & 6.24 & 0.86 & 54 & 15.6 & 3.15 & 0.59 & 3.20 & 3.77 & 0.10 & 0.5 \\
\hline \multirow{5}{*}{$\begin{array}{c}\text { Deep Well } \\
n=20\end{array}$} & Min & 152 & 5.47 & 25.4 & 170 & 0.00 & 0.75 & 0.15 & 0.07 & 62 & 17.0 & 0.83 & 2.23 & 1.94 & 0.21 & 0.01 & 3.0 \\
\hline & $\operatorname{Max}$ & 270 & 6.05 & 27.9 & 303 & 13.9 & 21.9 & 2.73 & 2.36 & 188 & 42.3 & 3.38 & 13.4 & 8.35 & 7.04 & 0.36 & 3.0 \\
\hline & Avg & 211 & 5.73 & 26.7 & 222 & 2.31 & 6.68 & 1.04 & 0.63 & 117 & 28.2 & 2.22 & 5.41 & 4.54 & 3.98 & 0.20 & 3.0 \\
\hline & Med & 200 & 5.73 & 26.8 & 206 & 0.02 & 3.26 & 0.89 & 0.40 & 117 & 28.0 & 2.15 & 5.04 & 4.90 & 4.30 & 0.22 & 3.0 \\
\hline & SD & 43 & 0.14 & 0.7 & 36 & 4.74 & 6.42 & 0.68 & 0.60 & 27 & 7.52 & 0.60 & 2.28 & 1.53 & 1.85 & 0.08 & 0.0 \\
\hline \multirow{5}{*}{$\begin{array}{l}\text { Halda River } \\
\quad \mathrm{n}=6\end{array}$} & Min & 2 & 6.51 & 27.7 & 118 & 5.86 & 1.69 & 0.41 & 0.31 & 58 & 6.31 & 1.03 & 7.48 & 4.92 & 0.02 & 0.01 & 3.0 \\
\hline & Max & 2 & 6.73 & 28.6 & 137 & 6.42 & 4.68 & 2.25 & 4.49 & 77 & 8.76 & 1.36 & 9.02 & 5.39 & 0.06 & 0.01 & 3.0 \\
\hline & Avg & 2 & 6.64 & 28.2 & 127 & 6.17 & 2.50 & 0.97 & 3.36 & 64 & 7.40 & 1.20 & 8.29 & 5.03 & 0.02 & 0.01 & 3.0 \\
\hline & Med & 2 & 6.67 & 28.3 & 125 & 6.21 & 2.13 & 0.77 & 3.83 & 60 & 7.06 & 1.19 & 8.31 & 4.97 & 0.02 & 0.01 & 3.0 \\
\hline & SD & 0 & 0.09 & 0.30 & 7.92 & 0.21 & 1.10 & 0.65 & 1.57 & 7.9 & 1.09 & 0.11 & 0.54 & 0.18 & 0.02 & 0.00 & 0.0 \\
\hline
\end{tabular}

(1997) for the parameters chloride $\left(\mathrm{Cl}^{-}\right)$, nitrate $\left(\mathrm{NO}_{3}^{-}\right)$and sulfate $\left(\mathrm{SO}_{4}^{2-}\right)$ are 150-600, 10 and $400 \mathrm{mg} / \mathrm{L}$ respectively [17]. The average concentrations of $\mathrm{NO}_{3}^{-}$ $(4.66,5.67,1.04$ and $0.97 \mathrm{mg} / \mathrm{L})$ and $\mathrm{SO}_{4}^{2-}(6.43,1.12,4.82$ and $3.36 \mathrm{mg} / \mathrm{L})$ in shallow, intermediate and deep aquifers, and Halda river are relatively lower.

The alkalinity (mainly consisting of $\mathrm{HCO}_{3}^{-}$) values upto $300 \mathrm{mg} / \mathrm{L}$ are usual in groundwater but landfill leachate or agricultural slurries can be many orders of magnitude greater than this [18]. Bi-carbonates $\left(\mathrm{HCO}_{3}^{-}\right)$(average concentrations of 217, 129 and $151 \mathrm{mg} / \mathrm{L}$ ) are the dominant anions in all groundwater samples of shallow, intermediate and deep aquifer respectively. The average $\mathrm{HCO}_{3}^{-}$value of Halda river samples is $64 \mathrm{mg} / \mathrm{L}$. The alkalinity shows an initial increase at shallow depths. The influence of atmospheric and biogenic $\mathrm{CO}_{2}$ probably accounts for increase in alkalinity maximum values in fresh groundwater samples of the overburden and in shallow, dilute or brackish bi-carbonate type bedrock groundwater samples. Calcite dissolution is also an evident source for alkalinity. Overall, it is probable that the variation in the alkalinity values is 
due to the contribution of carbonate minerals like calcite $\left(\mathrm{CaCO}_{3}\right)$ and dolomite $\left(\mathrm{CaMg}\left(\mathrm{CO}_{3}\right)_{2}\right)[19]$.

Among all major ions usually dissolved in water, chloride $\left(\mathrm{Cl}^{-}\right)$is the most conservative ion. The main sources of $\mathrm{Cl}^{-}$in groundwater are halite dissolution and rainfall [20]. The average Chloride concentrations of shallow, intermediate and deep groundwater are 22.08, 8.78 and $45.49 \mathrm{mg} / \mathrm{L}$ respectively, which are consistent with the EC values. Chloride concentration of all wells in the study area is below the permissible limit $(600 \mathrm{mg} / \mathrm{L})$ of DoE [17]. The average chloride value of Halda river samples is $2.50 \mathrm{mg} / \mathrm{L}$. The graphical representation of $\mathrm{Na}$ vs. $\mathrm{Cl}$ (Figure 5) reflects that all wells in the study area are not affected with high chloride concentrations. None of the groundwater samples fall on or near the dilution line of seawater and dissolution line of halite. Most samples are enriched in sodium, presumably as a result of water-rock interaction. It is seen that the $\mathrm{Na} / \mathrm{Cl}$ ratio for most of the water samples is higher than that of sea water fresh water mixing and majority of them fall in the field of freshening.

The maximum permissible limit of DoE [17] of cations sodium, potassium, calcium and magnesium are $200,12,75$ and $35 \mathrm{mg} / \mathrm{L}$ respectively. The $\mathrm{Na}^{+}$concentrations in shallow, intermediate and deep groundwaters of Madunaghat area vary from $25.61-85.53,17.83-67.93$ and $19.61-42.33 \mathrm{mg} / \mathrm{L}$ with average values of $40.36,34.98$ and $28.18 \mathrm{mg} / \mathrm{L}$ respectively. Similarly, the average values of $\mathrm{K}^{+}$, $\mathrm{Ca}^{2+}$ and $\mathrm{Mg}^{2+}$ for shallow, intermediate and deep groundwaters of Madunaghat area and Halda river water samples are given in Table 1 . The average concentrations of $\mathrm{Na}^{+}, \mathrm{K}^{+}, \mathrm{Ca}^{2+}$ and $\mathrm{Mg}^{2+}$ of Halda river water samples are 7.4, 1.2, 8.29 and $5.03 \mathrm{mg} / \mathrm{L}$ respectively.

\section{Hydrochemical Facies of Groundwater}

Piper diagrams [21] are widely used to present and classify major ions of groundwater and summarize the main contrasts in hydrochemical composition between different water sources [22]. The piper diagram (Figure 6) identifies

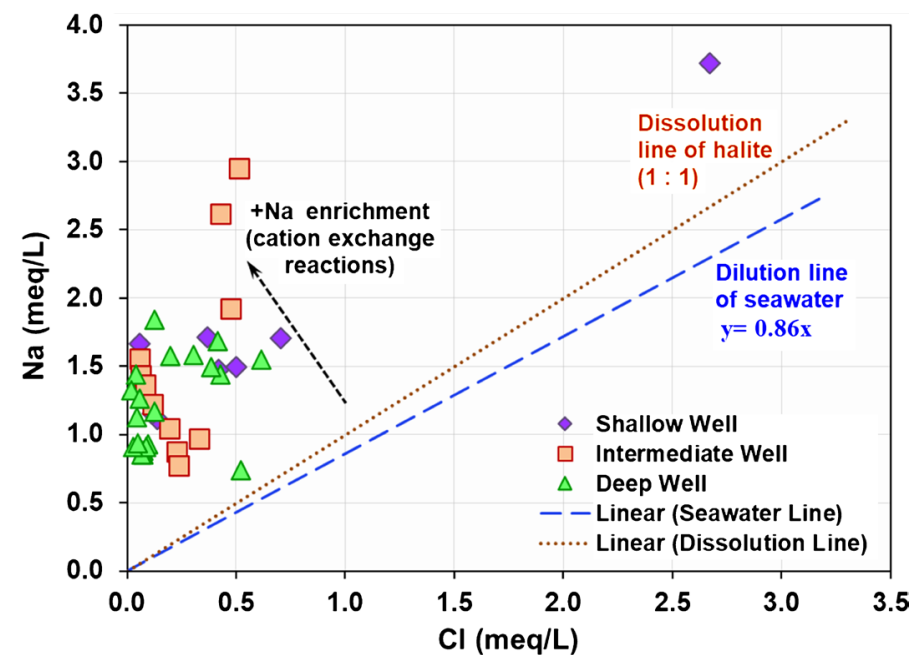

Figure 5. Sodium versus Chloride concentration for 39 wells representing different depths of aquifers. 


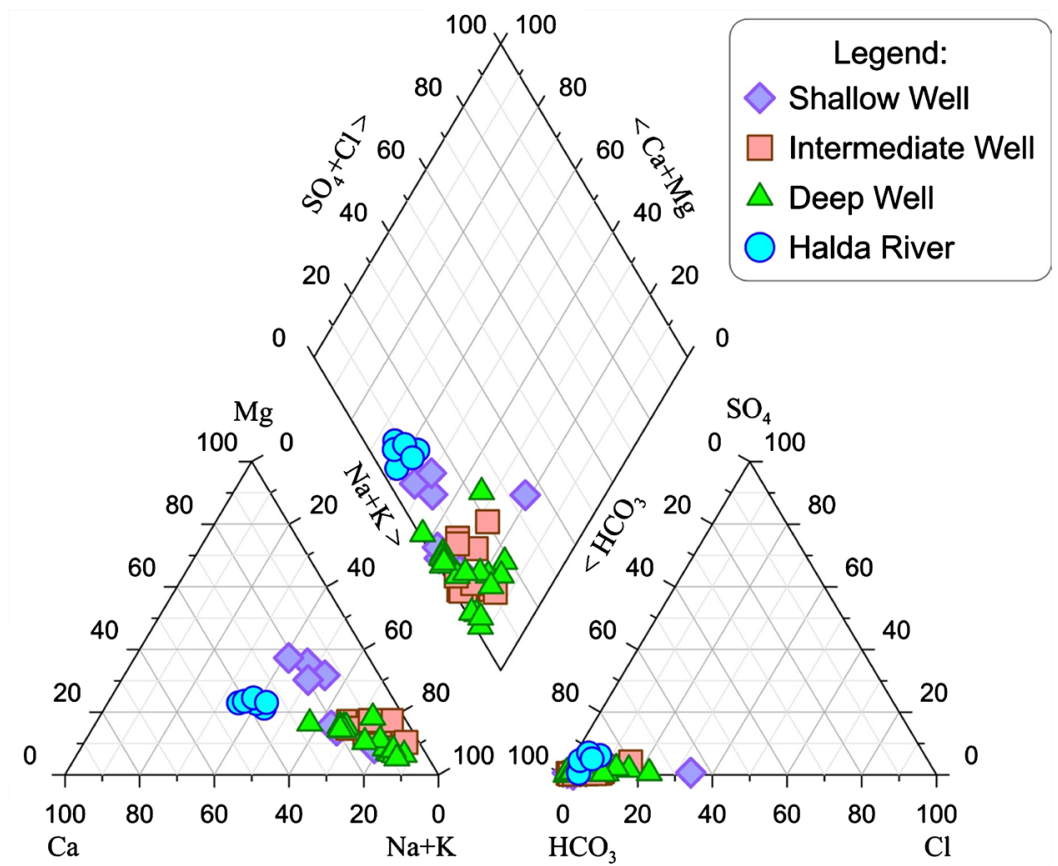

Figure 6. Piper Trilinear plot showing the percent composition of major ions in groundwater and river water samples from Madunaghat area, Chattogram.

low salinity groundwater samples throughout the study area with a mean electrical conductivity of $287 \mu \mathrm{S} / \mathrm{cm}$. Sodium content is about $90 \%$ of the cation portion in many samples. Sodium-rich hydrochemical facies, such as, $\mathrm{Na}-\mathrm{Mg}-\mathrm{HCO}_{3}$ and $\mathrm{Na}-\mathrm{HCO}_{3}$ are thus encountered in the intermediate and deep wells. Due to magnesium rich in the water of shallow wells mostly, the water type in the shallow aquifer is shown as $\mathrm{Mg}-\mathrm{Na}-\mathrm{HCO}_{3}$ [23]. The chloride content in the Halda river shows a little value ranging from $1.69 \mathrm{mg} / \mathrm{L}$ to $4.68 \mathrm{mg} / \mathrm{L}$. The position of the groundwater in the anions triangle indicates dominance of $\mathrm{HCO}_{3}^{-}$, but the absence of sulfate in the groundwaters. $\mathrm{HCO}_{3}$ is the dominant anion and its concentration is mainly attributed to weathering as well as organic matter degradation. $\mathrm{Na}^{+}$and $\mathrm{HCO}_{3}^{-}$concentrations come mainly from weathering of alkali-feldspars related with the recharge areas. $\mathrm{Na}-\mathrm{HCO}_{3}$ represents 'Fresh Type' water in the aquifer. The other two types of 'Blended Water' are found as $\mathrm{Mg}-\mathrm{Na}-\mathrm{HCO}_{3}$ in the shallow groundwater of Line Wells at Madunaghat BWDB compound and as $\mathrm{Na}-\mathrm{Mg}-\mathrm{HCO}_{3}$ in a few intermediate wells of mid-Holocene aquifer at North Madarsha. This blended type water is low mineralized water indicating the initial source of water recharging into the aquifer systems. The slightly increase in $\mathrm{Na}^{+}$exchange for $\mathrm{Mg}^{2+}$ suggest softening process, which may indicate much more water-rock interactions along the flow paths. The water type for Halda river is of $\mathrm{Mg}-\mathrm{Ca}-\mathrm{Na}-\mathrm{HCO}_{3}$ type.

\subsection{Trace and Toxic Elements}

1) Iron

About $83 \%$ of the groundwater samples have Fe concentration greater than 
$1.0 \mathrm{mg} / \mathrm{L}$, the maximum permissible level [17]. In this study, the Fe concentrations in groundwaters were found between 0.08 and $12.72 \mathrm{mg} / \mathrm{L}$, with a mean value $5.07 \mathrm{mg} / \mathrm{L}$. Highest Fe concentration (12.72 mg/L) was observed in shallow depth $(16 \mathrm{~m})$ at Madunaghat Bangladesh Water Development Board (BWDB) compound, South Madarsha. On the contrary, Halda river samples show very low concentration of $\mathrm{Fe}$ (minimum $0.02 \mathrm{mg} / \mathrm{L}$ and maximum $0.06 \mathrm{mg} / \mathrm{L}$ ). Higher Fe concentrations in the aquifers might have resulted from interaction of oxidized Fe minerals and organic matter and subsequent dissolution of $\mathrm{Fe}_{2} \mathrm{CO}_{3}$ at a comparatively lower $\mathrm{pH}$ [24]. This type of water is clear when drawn from the well, but shortly changes into cloudy and then turns brown due to precipitation of $\mathrm{Fe}(\mathrm{OH})_{3}$ [23], which is a common problem in some parts of the study area.

\section{2) Manganese}

In collected groundwater samples, Manganese $(\mathrm{Mn})$ concentration is found in the range of 0.005 to $1.46 \mathrm{mg} / \mathrm{L}$. Only three out of 39 groundwater samples have higher concentration of $\mathrm{Mn}$, that is, $0.99-1.46 \mathrm{mg} / \mathrm{L}$ greater than the permissible limit, and these three samples were collected from the line wells (LW-1, LW-2 and LW-3) located close to Halda river bank. The samples of the Halda river contain low level $\mathrm{Mn}$ (average $0.005 \mathrm{mg} / \mathrm{L}$ ) due to presence of oxidizing environment in river water. The WHO health-based guideline value for $\mathrm{Mn}$ in drinking water is $0.40 \mathrm{mg} / \mathrm{L}$ [25]. The Bangladesh Standard value of $\mathrm{Mn}$ is 0.10 $\mathrm{mg} / \mathrm{L}$ [17]. Manganese is an extra problem in the groundwaters, both on acceptability and potential health grounds [26].

\section{3) Arsenic}

The presence of arsenic (As) in drinking water has been associated with adverse health outcomes, primarily cancers, and currently is regulated by Bangladesh standards for public water systems. The final ruling by the DoE on arsenic in drinking water has set the standard as $50 \mu \mathrm{g} / \mathrm{L}$ [17]. Data from randomly selected private domestic wells, monitoring wells and production wells of CWASA throughout the study area show that the intermediate and deep wells have water with As concentrations less than the detection limit $3.0 \mu \mathrm{g} / \mathrm{L}$. Only a few shallow wells have As concentrations greater than the detection limit varying from 13.7 $47.4 \mu \mathrm{g} / \mathrm{L}$, which is less than the DoE permissible limit.

\subsection{Environmental Isotopes}

\subsubsection{Stable Isotopes in Precipitation}

A precipitation network, covering mainly the study area (Figure 1), has been established in the complex of Mohora WTP for rainfall sampling. The rainfall samples were collected as a monthly composite, from this station, during a period of two years from October 2013 to October 2015. Figure 7 shows the deuterium and oxygen-18 relation of precipitation for all the samples collected from the rainfall stations in Chattogram. The $\delta^{18} \mathrm{O}$ values vary from $-11.93 \%$ o to $-0.57 \%$ o with an average of $-5.61 \%$ and those of $\delta^{2} \mathrm{H}$ from $-72.77 \%$ o to $+13.79 \%$ with an average of $-35.4 \%$. Seasonal variation in the isotope values is clearly seen with enriched values in February and March compared to other months (Figure 7). 


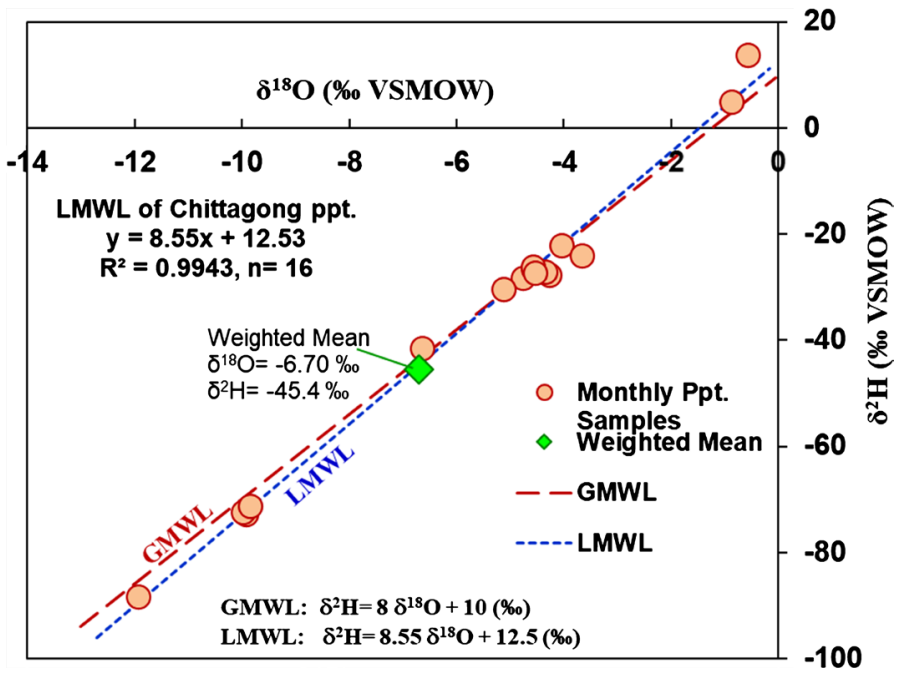

Figure 7. Plots of Local Meteoric Water Line (LMWL) for Chattogram. Also shown is the weighted mean annual isotopic composition of precipitation (green colour diamond).

The equation of the least squares regression line fitting all of the sampled rain water near the study area is given by the following equation.

$$
\delta^{2} \mathrm{H}=8.55 \cdot \delta^{18} \mathrm{O}+12.5 \text { (in \%o VSMOW) with } R^{2}=0.994 \text { and } n=16
$$

This equation defines the Local Meteoric Water Line (LMWL) slightly higher than that of Global Meteoric Water Line (GMWL). GMWL defines the relationship between ${ }^{2} \mathrm{H}-{ }^{18} \mathrm{O}$ in precipitation on a global scale and has the relation: $\delta^{2} \mathrm{H}$ $=8 \cdot \delta^{18} \mathrm{O}+10$ [27]. The slope of this line $(8.55 \%)$ is slightly higher than the slope (8) of GMWL. The higher intercept $(12.5 \%$ ) might be attributed to the effects of vapor recirculation along the transportation of air masses and also due to intraseasonal variability of precipitation [28].

Dansgaard (1964) defined the deuterium excess as $d$-excess $=\delta \mathrm{D}-8 \cdot \delta^{18} \mathrm{O}$ [29]. The $d$-excess is a useful tracer of vapor source and has been related to meteorological conditions at vapor source regions and to vapor recycling over the continents. The $d$-excess indicates the effect of secondary evaporation. The global mean value of $d$-excess is approximately $+10 \%$. The $d$-excess values in pre-monsoon and post monsoon are slightly greater than $+10 \%$. The increase of $d$-excess has been attributed to the moisture originating from the Bay of Bengal, which is characterized by lower relative humidity conditions prevailing in this region [28]. But the $d$-excess values in monsoon show lower than $10 \%$ indicating the chance of secondary evaporation effects. The average of $d$-excess values is $9.46 \%$ VSMOW slightly lower than 10 . The high $d$-excess values are mostly observed in the pre-monsoon precipitation.

\subsubsection{Stable Isotope Compositions in Sampled Groundwater and River Water}

The $\delta$-diagram for all observed shallow, intermediate and deep groundwaters as well as Halda river water in Madunaghat area are shown in Figure 8. Most of the groundwater samples fall close to and sub-parallel to GMWL. This indicates that 


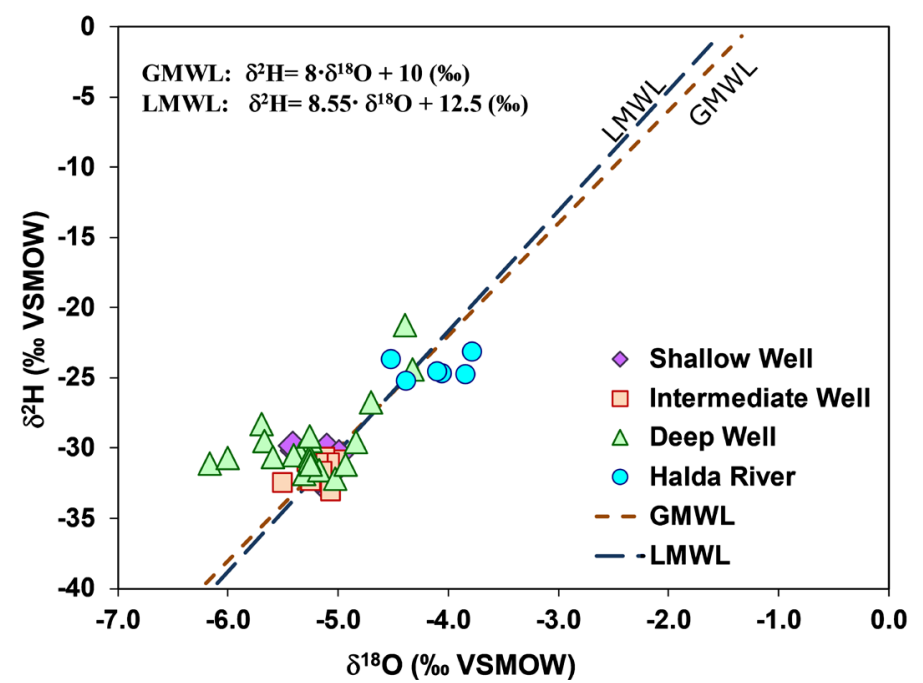

Figure 8. Plots of $\delta \mathrm{D}$ versus $\delta^{18} \mathrm{O}$ along with GMWL and LMWLs for shallow, intermediate and deep groundwater, and river water.

groundwater recharge is mainly sourced from precipitation and/or flood water, and is weakly affected by evaporation. Mostly, the $\delta^{8 \mathrm{H}}$ vs. $\delta^{88} \mathrm{O}$ fields of deep, intermediate and shallow groundwater are overlapping. Deep (150 - $270 \mathrm{~m}$ depth) groundwater has $\delta^{18} \mathrm{O}-4.32 \%$ to $-6.17 \%$ and $\delta^{8} \mathrm{H}-21.28 \%$ to $-32.21 \%$; intermediate (60 - $75 \mathrm{~m}$ depth) groundwater has $\delta^{8} \mathrm{O}-5.02 \%$ to $-5.28 \%$ and $\delta \mathrm{H}-30.66 \%$ to $-33.06 \%$; and shallower ( $<50 \mathrm{~m}$ depth) groundwater has $\delta^{88} \mathrm{O}-5.00 \%$ o to $-5.41 \%$ o and $\delta \mathrm{H}-29.86 \%$ o to $-32.61 \%$. These isotopic features suggest that most of the groundwaters results from a mixing between recent recharge and an older component recharge under climatic conditions cooler than at present [5].

The isotope data suggest much of the water is derived from similar sources and has undergone evaporation. Overlap of some of the data from shallow groundwater samples and data points from deeper aquifer sources suggests a degree of commonality of source for some sites [30]. Both shallow and deep groundwater data sets have trends that diverge from the LMWL and GMWL by a shallower slope suggestive of an evaporative component to the water. It is difficult to determine if evaporation has occurred during precipitation in the summer months, if evaporation occurred prior to infiltration, or if the evaporation has occurred as a process within the vadose zone [31].

Some isotope compositions of the deep groundwater samples with only depleted oxygen isotope values fall above the GMWL and LMWL. This indicates the effect of non-equilibrium fractionation of atmospheric vapor before infiltration. For the stable isotope composition of the Halda river running course, the mean values of $\delta^{8} \mathrm{O}$ increase along the river course during high tide. The $\delta^{8} \mathrm{O}$ and $\delta^{8} \mathrm{H}$ values for the Halda river samples ranged from $-4.52 \%$ to $-3.78 \%$ and $-25.23 \%$ o and $-23.11 \%$ respectively and with the mean $\delta^{18} \mathrm{O}$ values of $-4.11 \%$. The river samples fall below the meteoric water line showing the evaporation effect.

The spatial distribution map (Figure 9) of Oxygen-18 plays an important role in characterization of meaningful and useful patterns of isotope variation 


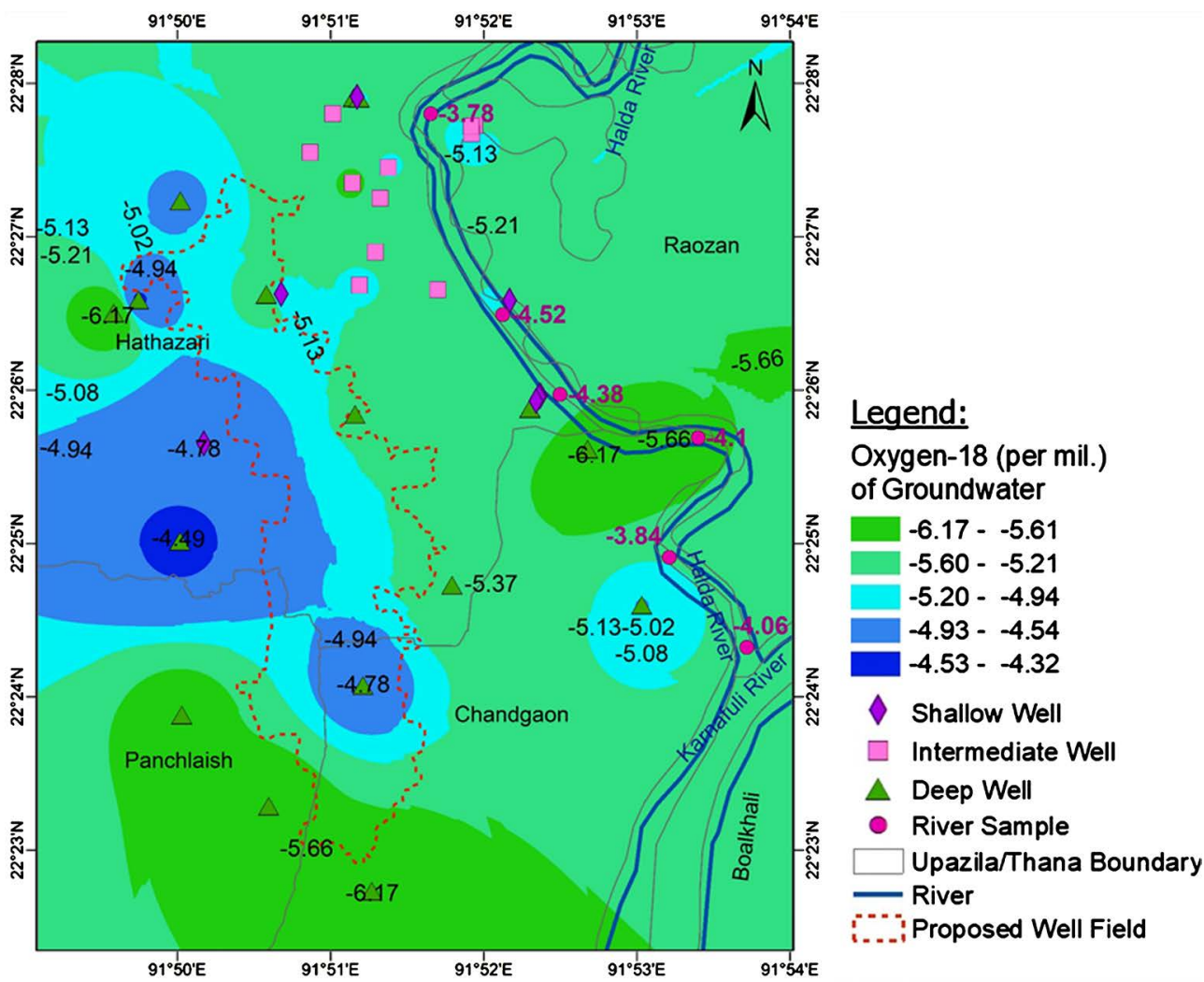

Figure 9. Spatial distribution of Oxygen-18 of all groundwater samples. The oxygen-18 values of Halda river water are indicated in purple color.

pertaining to groundwater recharge. More enriched water depicted by deep blue color occurs in the western part of the study area. In the eastern and southern part, the overlapping of different stage of water shows gradual isotopic depletion depicted by light blue to deep greenish color.

\subsubsection{Radioactive Isotopes in Sampled Water \\ 1) Tritium Dating}

The tritium $\left({ }^{3} \mathrm{H}\right)$ content of shallow, intermediate and deep groundwaters in the study area range from 0.28 to $3.10 \mathrm{TU}, 0.04$ to $0.21 \mathrm{TU}$ and 0.00 to $0.16 \mathrm{TU}$ respectively. Meanwhile, the Halda river water tritium values range from 1.80 to 2.70 TU. The shallow groundwater samples have higher tritium values, it indicates that the aquifers are nourished by active recharge. The qualitative interpretation of observed groundwater samples show that the shallow groundwaters are recharged within the aquifers before 1990 and the waters with the absence of ${ }^{3} \mathrm{H}$ are recharged before 1960s. The wells tapping the intermediate and deep groundwater in and around Madunaghat area contain practically no detectable tritium and the values are generally less than $0.20 \mathrm{TU}$ which is the detection limit of tritium measurement. In recent waters, ${ }^{3} \mathrm{H}$ originates mainly from the atmospheric thermonuclear bomb tests conducted during the 1950s and 1960s, with subsequent incorporation of ${ }^{3} \mathrm{H}$ into the water cycle by oxidation [32].

In the depth versus ${ }^{3} \mathrm{H}$ plot (Figure 10$)$, wide range $(0.28-3.10 \mathrm{TU})$ of tritium 
values are observed up to the depth $50 \mathrm{~m}$ and the groundwater below $50 \mathrm{~m}$ depth shows ${ }^{3} \mathrm{H}$ content $<1.0 \mathrm{TU}$. Thus groundwaters having depth less than $50 \mathrm{~m}$ and tritium value less than $1.0 \mathrm{TU}$ indicate recharge to the greater depths. The Halda river water has tritium content from 1.95 to $6.49 \mathrm{TU}$. The tritium contents of line well (shallow groundwaters) are consistent with recharge from local rain and floodwaters.

Spatial distribution of Tritium of all groundwater samples shows (Figure 11)

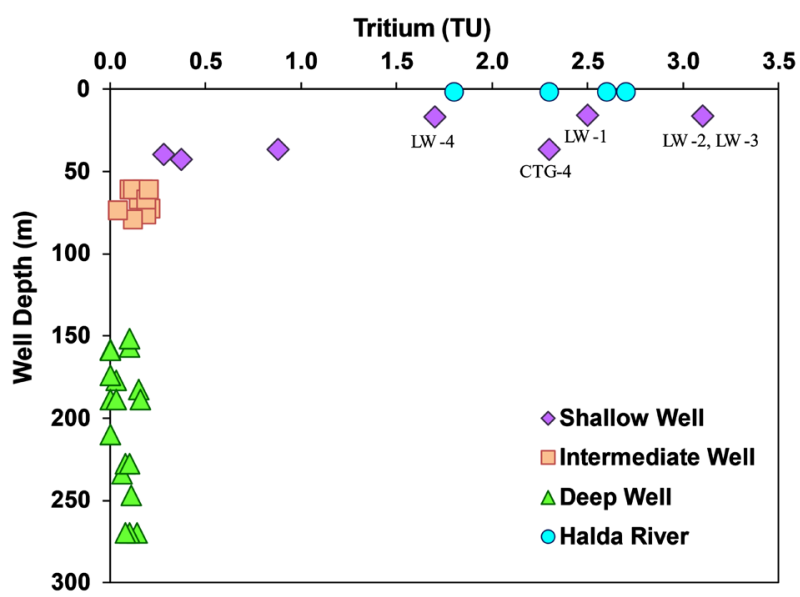

Figure 10. Depth distribution of Tritium content in groundwater of study area. The round blue colour shows the Tritium content in Halda river.

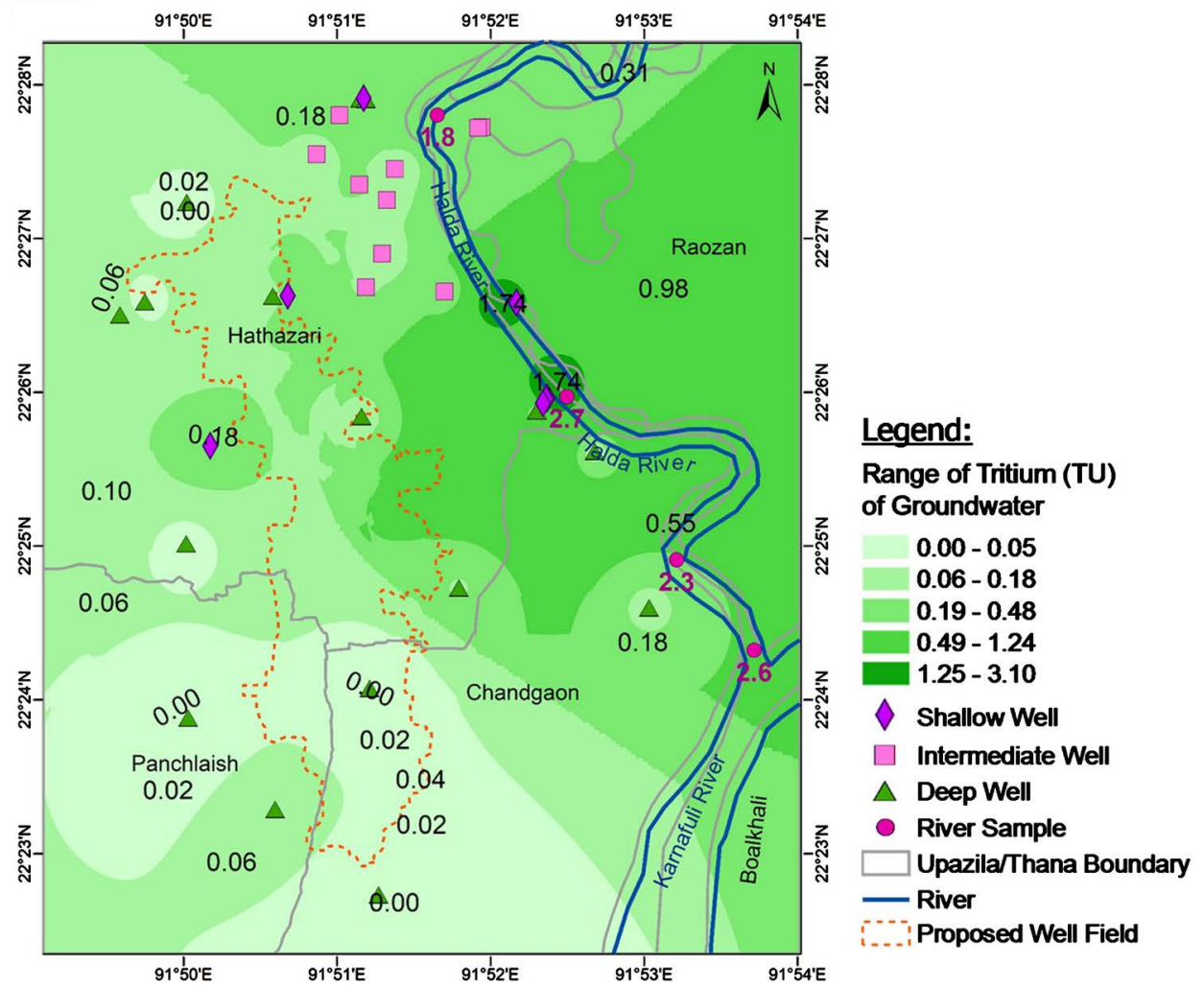

Figure 11. Spatial distribution of Tritium of all groundwater samples. The Tritium values of Halda river water are indicated in purple colour. 
the older recharge in the western part of the study area and a few deep groundwaters have positive tritium values in the north western part. The contour values in the eastern part show higher tritium values indicating the recharge sub-modern to modern.

\section{2) Carbon-14 Dating}

Carbon-14 $\left({ }^{14} \mathrm{C}\right)$ activity of the analyzed groundwater samples varies from 59.34 to $16.22 \mathrm{pMC}(\mathrm{n}=12)$ in intermediate to deep aquifers (Figure 12). Carbon-14 results are given here in terms of "apparent radiocarbon age" (i.e. an age calculated assuming an initial value of $100 \mathrm{pMC}$ and no dilution occurs other than decay). The law of radioactive decay provides the basic relationship by which radioactive dating is determined [33]. The groundwater age (since infiltration) would be given as:

$$
T_{m}=-\left(T_{1 / 2} / \ln 2\right) \times \ln \left(C_{t} / C_{0}\right)=-8267 \ln \left(C_{t} / C_{0}\right)
$$

where, $T_{1 / 2}$ is the half life of ${ }^{14} \mathrm{C}[5730 \mathrm{y}], \mathrm{C}_{\mathrm{t}}$ is the ${ }^{14} \mathrm{C}$ activity of the sample or measured activity in counts per minute, and $\mathrm{C}_{\mathrm{o}}$ is the initial ${ }^{14} \mathrm{C}$ activity of the modern standard in counts per minute. As calculated, the groundwater ages in and around Madunaghat well field area range from 4300 to 15,000 years before present (BP). As seen from the spatial distribution of Carbon-14 (Figure 13), comparatively low ${ }^{14} \mathrm{C}$ values are observed in the western part of the study area. It shows consistency with the isoscape distribution of tritium data of Madunaghat area. The higher apparent DIC ages indicate confinement of the aquifer in the western boundary. If mixing occurs with younger groundwater, measured ages may be underestimated. Tritium values would indicate the presence of a "young" component to the groundwater. Notwithstanding these limitations the ages measured indicate that the deeper water-bearing units have very long residence times due to very long flow paths from recharge areas, slow velocities or a combination of the two. Samples with almost no tritium have

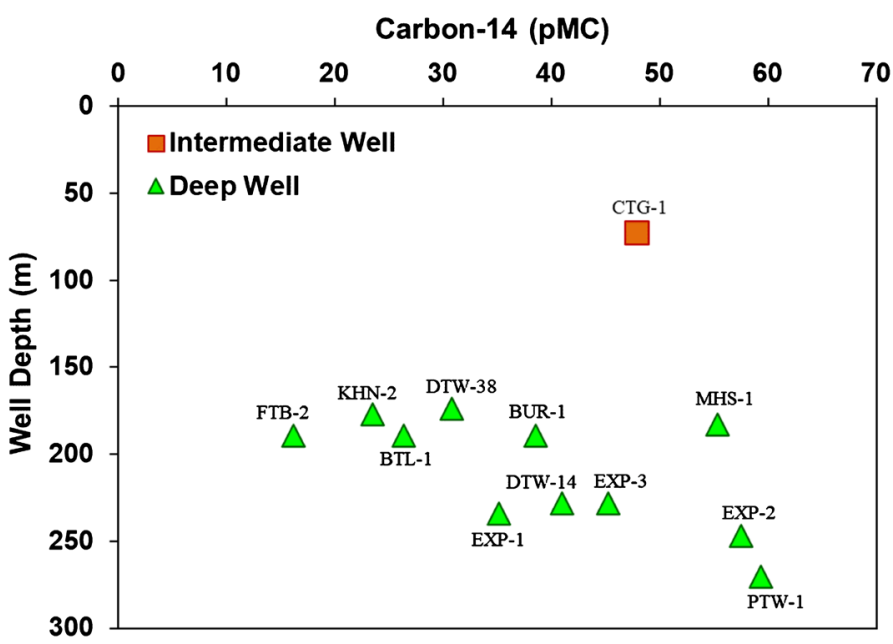

Figure 12. Depth distribution of ${ }^{14} \mathrm{C}$ activity in groundwater in and around Madunaghat well field area. The sample IDs of intermediate and deep wells are shown with the symbols. 


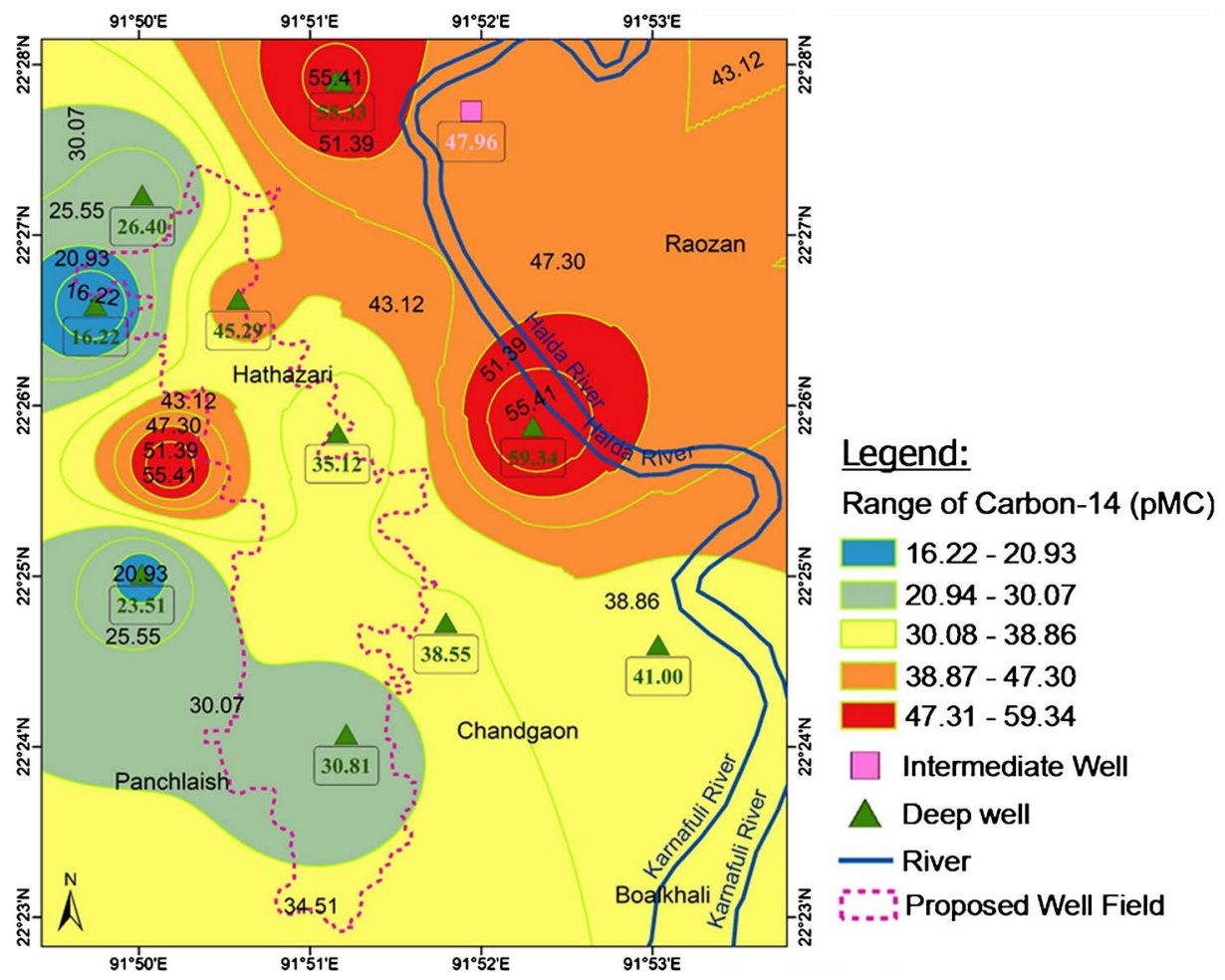

Figure 13. Spatial distribution of Carbon-14 (pMC) of intermediate to deep groundwater samples.

lower C-14 values of 16.22 to $30.81 \mathrm{pMC}$. The deep monitoring wells have higher carbon-14 value (59.34 pMC) indicating mixing with some modern to sub-modern groundwater.

\subsubsection{Isotopic Evidence of Mixing of River Water with Shallow Groundwater}

The plot of oxygen-18 vs. tritium (Figure 14) of groundwater at Madunaghat area deciphers the connectivity of Halda river water with the shallow groundwater system. The higher tritium values (1.7 to $3.1 \mathrm{TU}$ ) are derived from the line wells installed particularly in shallow depth $(16 \mathrm{~m})$ close to Halda river which has similar tritium values (1.8 to $2.8 \mathrm{TU}$ ).

On the other hand, the tritium content vs. chloride of the groundwater and Halda river water samples are plotted to see the evidence of mixing condition (Figure 15). The plot indicates that the Halda river is feeding to the shallow line wells progressively as its tritium values are closer to each other, suggesting that gradual dissolution or reaction with shallow aquifer materials is the dominant mechanism. The chloride contents in the line wells vary from 13.06 to 25.0 $\mathrm{mg} / \mathrm{L}$, which are less than the DoE permissible limit $(600 \mathrm{mg} / \mathrm{L})$ [17]. As observed, the groundwater is not affected by salinity.

\subsubsection{Isotopic Signature of Deep Groundwater}

As seen from $\delta^{13} \mathrm{C}$ vs. ${ }^{14} \mathrm{C}$ plot (Figure 16), carbon-14 increases with the depletion of Carbon-13 values. The enriched C-13 values with lowest $\mathrm{C}-14$ values indicate old and fresh groundwater. With the higher C-14 and depleted C-13 


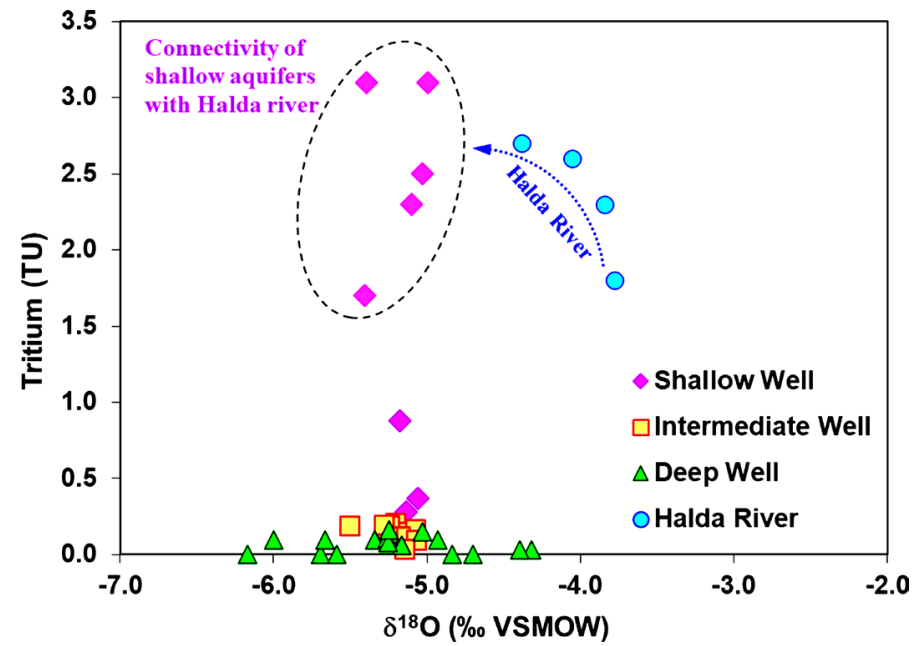

Figure 14. Relationship between $\delta^{18} \mathrm{O}$ and Tritium shows the connectivity between Halda river and adjacent shallow aquifer.

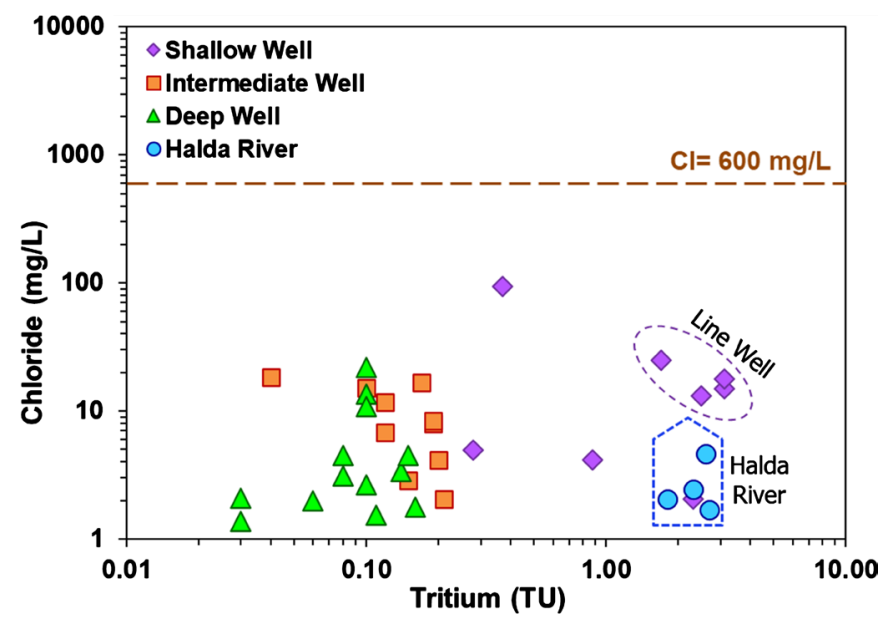

Figure 15. High tritium values of Halda river and line wells indicate the mixing between river water and shallow aquifer.

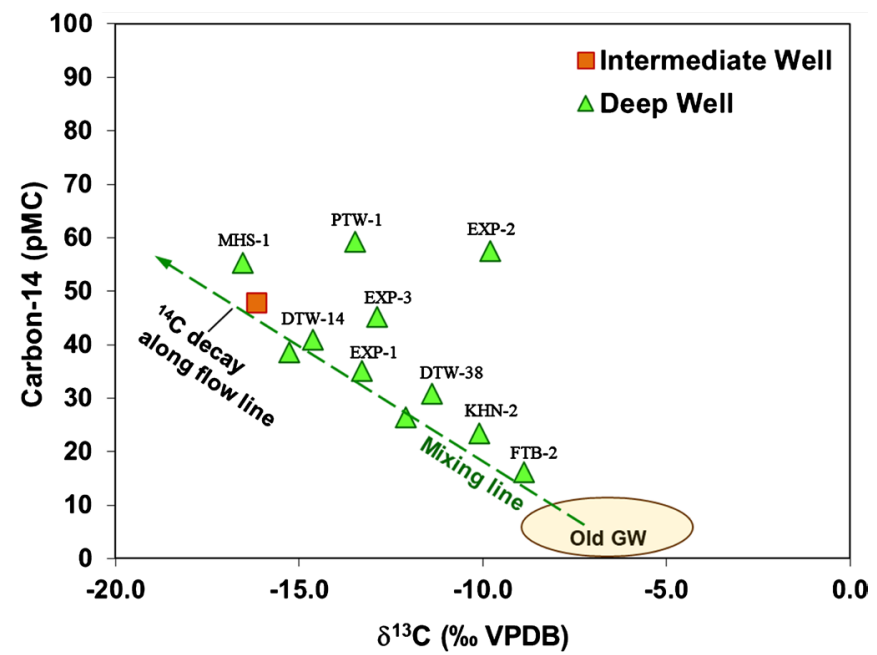

Figure 16. Stable carbon isotope and carbon-14 compositions of groundwater of Madunaghat area (Decrease of ${ }^{14} \mathrm{C}$ values with the enrichment of $\delta^{13} \mathrm{C}$ ). 
values, it shows some mixing trend. The $\delta^{13} \mathrm{C}$ values of groundwater range from $-4.20 \%$ to $-16.97 \%$ VPDB. These slightly enriched $\delta^{13} \mathrm{C}$ values (ranging from $-4.20 \%$ to $-8.87 \%$ VPDB) in groundwaters reflect derivation of DIC from dissolution of carbonate minerals. On the other hand, the high $\delta^{13} \mathrm{C}$ (more negative) values of the other intermediate and deep wells may reflect an isotopic exchange with atmospheric $\mathrm{CO}_{2}$.

Samples with almost no tritium have lower C-14 values of 16.22 to $30.81 \mathrm{pMC}$. The Carbon-14 contents of intermediate to deep groundwater samples vary from 16.2 to $59.3 \mathrm{pMC}$. The apparent groundwater ages range from 4300 to 15,000 years BP, i.e., the aquifers of sampled groundwater were recharged a long time ago.

\subsubsection{Investigating Salinity in the Groundwater System}

In the $\mathrm{Cl}^{-} \delta^{18} \mathrm{O}$ diagram (Figure 17), the mixing line between values of rainwater and seawater are plotted with the measured chemical and isotopic data. The isotopic data from the end member is the weighted mean of Oxygen-18 derived from the rainfall of Chattogram station nearing to the study area. Sea water is defined by $\delta^{18} \mathrm{O}=0 \%$ and $\mathrm{Cl}^{-}=19,000 \mathrm{ppm}$ [34]. The waters from the deep, intermediate and shallow wells do not fall on the mixing line, which confirms that the enrichment of the heavy oxygen isotope in these samples is due to evaporation effects [35]. This relationship between chloride and oxygen-18 $\left(\mathrm{Cl}-\delta^{18} \mathrm{O}\right)$ confirms that there is no effect of salinity in the present aquifer system in the study area.

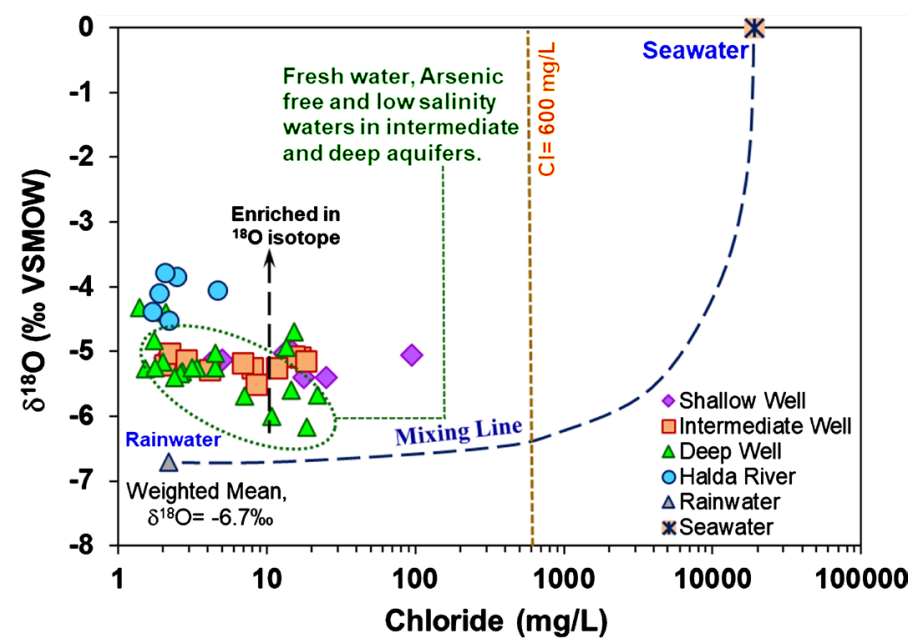

Figure 17. Oxygen-18 and Chloride in the groundwater samples of Madunaghat area, Chattogram.

\section{Conclusions}

This study has provided a better understanding on the hydrologic, geochemical and groundwater residence time in the aquifer system of the Madunaghat well field area. The combined interpretation of isotopic and chemical data of shallow, intermediate and deep groundwater, and adjacent Halda river give the following insights. 
- The $\delta^{18} \mathrm{O}$ and $\delta \mathrm{D}$ data indicate that all GWs derived from rainfalls and/or flood water are subject to some evaporation during infiltration. Overlap of some of the stable isotope data of shallow and deep suggests the similar sources. The isotopic features suggest that most of the groundwater results from a mixture between recent recharge and an older component recharge under climatic conditions cooler than at present. The Halda river samples fall below the meteoric water line showing the evaporation effect.

- The interconnectivity between shallow aquifers and river waters are mostly found in the line wells installed particularly in shallow depth $(16 \mathrm{~m})$ close to Halda river as evidenced from the similar tritium values of sampled line well water with the Halda river water. The plot of tritium content and chloride of the groundwater and Halda river water samples indicate that the Halda river is feeding to the shallow line wells progressively as its tritium values are closer to each other, suggesting that gradual dissolution or reaction with shallow aquifer materials is the dominant mechanism.

- The $\mathrm{Na} / \mathrm{Cl}$ ratio for most of the groundwater samples is higher than that of sea water fresh water mixing line and the majority of them fall in the field of freshening. The geochemistry of intermediate and deep groundwater is dominated by $\mathrm{Na}-\mathrm{Mg}-\mathrm{HCO}_{3}$ and $\mathrm{Na}-\mathrm{HCO}_{3}$ type waters. As the waters from all the wells do not fall on the seawater mixing line, it confirms that there is no effect of salinity in the present aquifer system in the study area.

- Increasing carbon-14 with the depletion of Carbon-13 indicates some mixing trend. The enriched C-13 values with the lowest $\mathrm{C}-14$ values indicate old and fresh groundwater. Samples with almost no tritium have lower C-14 values of 16.22 to 30.81 pMC. The Carbon-14 contents of intermediate to deep groundwater samples vary from 16.2 to $59.3 \mathrm{pMC}$ focusing the residence time in the range of 4300 to 15,000 years BP, i.e., the sourced water recharged the aquifers a long time ago.

The study helps in understanding the potential of intermediate and deep aquifer as a source of safe drinking water. A careful and systematic scientific study, including simple geophysical logging and chemical analysis, needs to be made before a substantial number of deep tube wells for water extraction is installed. Moreover, the benefit as identified for the end user from this study is to enable the planners and decision makers to identify the safe aquifer for drinking water of low salinity. Circumstantially, the test wells should be installed in the target aquifers and regular water quality tests should be conducted in the field and/or laboratory as appropriate.

\section{Acknowledgements}

The study was carried out under the framework of IAEA Technical Cooperation project BGD/7/007. The support for environmentally stable and radioactive isotope analyses provided by IAEA, Vienna, Austria is greatly appreciated and acknowledged. The cooperation of local DPHE and CWASA officials during field 
sampling is recognized. Finally, we acknowledge the logistic assistance from CWASA from its project CWSISP supported by World Bank; through a contract with the Institute of Water Modelling (IWM). Last but not the least, we would like to recognize the support and contributions of late senior hydrogeologist Mr. Mizanur Rahman of IWM in this study.

\section{Disclaimer}

The findings, interpretations and conclusions expressed in this paper are solely attributable to the authors and are not related to BAEC, IWM, CWASA or World Bank.

\section{Conflicts of Interest}

The authors declare no conflicts of interest regarding the publication of this paper.

\section{References}

[1] Chisty, K.U. (2014) Landslide in Chattogram City: A Perspective on Hill Cutting. Journal of Bangladesh Institute of Planners, 7, 1-17.

[2] BBS (2001) Statistical Yearbook of Bangladesh. Bangladesh Bureau of Statistics, Dhaka, Bangladesh.

[3] Rahman, M.M., Haughton, G. and Jonas, A.E.G. (2010) The Challenges of Local Environmental Problems Facing the Urban Poor in Chittagong, Bangladesh: A Scale-Sensitive Analysis. Environment and Urbanization, 22, 561-578. https://doi.org/10.1177/0956247810377560

[4] Islam, S. and Miah, S. (2003) Banglapedia: National Encyclopedia of Bangladesh. Asiatic Society of Bangladesh, Dhaka, 3, 491.

[5] Aggarwal, P.K., Basu, A. R., Poreda, R.J., Kulkarni, K.M., Froehlich, K., Tarafdar, S.A., Ali, M., Ahmed, N., Hussain, A., Rahman, M. and Ahmed, S.R. (2000) A Report on Isotope Hydrology of Groundwater in Bangladesh: Implications for Characterisation and Mitigation of Arsenic in Groundwater, IAEA, Vienna.

[6] Ahmed, N., Welch, A.H., Aggarwal, P.K., Wallin, B.G., Majumder, R.K. and Hossain, S. (2009) Isotopic and Hydrochemical Approaches in Understanding the Potential of Deep Aquifer in the Meghna Basin, Eastern of Bangladesh. Proceedings of International Conference of GeoDev, Dhaka, Bangladesh, 26-31 October 2009, 301-308.

[7] Hoque, M.A. and Burgess, W.G. (2012) ${ }^{14}$ C Dating of Deep Groundwater in the Bengal Aquifer System, Bangladesh: Implications for Aquifer Anisotropy, Recharge Sources and Sustainability. Journal of Hydrology, 444-445, 209-220. https://doi.org/10.1016/j.jhydrol.2012.04.022

[8] Majumder, R.K., Halim, M.A., Saha, B.B., Ikawa, R., Nakamura, T., Kagabu, M. and Shimada, J. (2011) Groundwater Flow System in Bengal Delta, Bangladesh Revealed by Environmental Isotopes. Environmental Earth Sciences, 64, 1343-1352. https://doi.org/10.1007/s12665-011-0959-2

[9] Majumder, R.K., Halim, M.A., Shimada, J., Saha, B.B., Kariya, K. and Keiko, S. (2019) Groundwater Salinization in Southwestern Coastal Aquifers of Bangladesh Revealed by Hydrochemistry and Isotopic Studies. International Journal of Geology 
and Mining, 5, 281-293.

[10] Hossain, M.S., Bashar, K. and Ahmed, N. (2008) An Approach to Hydrogeological Zonation: A Case Study for the Coastal Part of the Chattogram City. Bangladesh Geoscience Journal, 14, 33-55.

[11] Kamal, A.S.M.M. and Khan, M.A.A.M. (2006) Remote Sensing and GIS-based Urban Area Delineation on Geological Units of Chattogram City Area Bangladesh. Unpublished MSc Thesis, Department of Geology, University of Dhaka, Bangladesh.

[12] Zahid, A., Ali, M.H., Islam, F., Hassan, M.R., Islam, K. and Ahmed, N. (2018) Analysis of Aquifer Pumping Test Data to Determine Deep Groundwater Security in Southeastern Bangladesh. Journal of Natural Resources and Development, 8, 125-143.

[13] U.S. Geological Survey (1998) National Field Manual for the Collection of Water-Quality Data, In: Handbooks for Water Resources Investigations, U.S. Department of the Interior, Columbia.

[14] USEPA (1998) Technical Protocol for Evaluating Natural Attenuation of Chlorinated Solvents in Ground Water. United States Environmental Protection Agency, Document EPA/600R-98/128.

[15] Mazor, E. (2004) Chemical and Isotopic Groundwater Hydrology. 3rd Edition, Marcel Dekker, Inc., New York. https://doi.org/10.1201/9780203912959

[16] Tareq, S.M., Rahaman, M.S., Rikta, S.Y., Islam, S.M.N. and Sultana, M.S. (2013) Seasonal Variations in Water Quality of the Ganges and Brahmaputra, River, Bangladesh. Jahangirnagar University Environmental Bulletin, 2, 71-82. https://doi.org/10.3329/jueb.v2i0.16332

[17] ECR (1997) Standards for Drinking Water, Schedule-3. The Environment Conservation Rules, 1997, Ministry of Environment and Forestry, Government of Bangladesh.

[18] Kiely, G. (1997) Environmental Engineering. McGraw Hill Publishers, New York, 979.

[19] Drever, J.I. (1997) The Geochemistry of Natural Waters, Surface and Groundwater Environments. 3rd Edition, Prentice-Hall Publishers, Hoboken, 436.

[20] Haldorsen, S., Riise, G., Swensen, B. and Sleiten, R. S. (1997) Environmental Isotopes in Catchments, In: Saether, O.M. and de Caritat, P., Eds., Geochemical Processes, Weathering and Groundwater Recharge in Catchments, Balkema Publishers, Rotterdam, 400.

[21] Piper, M. (1944) A Graphic Procedure in Geochemical Interpretation of Water Analysis. Eos, Transactions American Geophysical Union, 25, 914-928. https://doi.org/10.1029/TR025i006p00914

[22] Soulsby, C., Chen, M., Ferrier, R.C., Helliwell, R.C., Jenkins, A. and Harriman, R. (1998) Hydrogeochemistry of Shallow Groundwater in an Upland Scottish Catchment. Hydrological Processes, 12, 1111-1127. https://doi.org/10.1002/(SICI)1099-1085(19980615)12:7<1111::AID-HYP633>3.0.C $\underline{0 ; 2-2}$

[23] Heim, J.D. (1991) Study and Interpretation of the Chemical Characteristics of Natural Water. United States Geological Survey, Water Supply Paper, No. 2254.

[24] Mondal, N.C., Singh, V.S., Puranik, S.C. and Singh, V.P. (2010) Trace Element Concentration in Groundwater of Pesarlanka Island, Krishna Delta, India. Environmental Monitoring and Assessment, 163, 215-227. https://doi.org/10.1007/s10661-009-0828-6 
[25] World Health Organization (WHO) (2004) Guidelines for Drinking-Water Quality. 3rd Edition, Vol. 1, WHO, Geneva.

[26] BGS and DPHE (2001) Arsenic Contamination of Groundwater in Bangladesh. Vol. 2, Final Report, BGS Technical Report WC/00/19.

[27] Craig, H. (1961) Isotopic Variations in Meteoric Waters. Science, 133, 1702-1703. https://doi.org/10.1126/science.133.3465.1702

[28] Ahmed, N., Kurita. N, Chowdhury, M.A.M., Gao, J., Hassan, S.M.Q, Mannan, M.A. Mallik, M.A.K., Choudhury, S.A., Abdul Quaiyum Bhuiyan, M.A.Q. and Masud Karim, M.M. (2020) Atmospheric Factors Controlling Stable Isotope Variations in Modern Precipitation of the Tropical Region of Bangladesh. Isotopes in Environmental and Health Studies, 56, 220-237. https://doi.org/10.1080/10256016.2020.1770245

[29] Dansgaard, W. (1964) Stable Isotopes in Precipitation. Tellus, 16, 436-467. https://doi.org/10.3402/tellusa.v16i4.8993

[30] Smith, D.L. and Guitjens, J.C. (1998) Characterization of Urban Surfacing Ground Water in Northwest Henderson, Clark County, Nevada. Environmental and Engineering Geoscience, 4, 455-477. https://doi.org/10.2113/gseegeosci.IV.4.455

[31] Kendall, C. and Coplen, T.B. (2001) Distribution of Oxygen-18 and Deuterium in River Waters across the United States. Hydrological Processes, 15, 1363-1393. https://doi.org/10.1002/hyp.217

[32] Klump, S., Kipfer, R., Olaf, A.C., Harvey, C.F., Brennwald, M.S., Khandkar, N.A., Badruzzaman, A.B.M., Hug, S. and Imboden, D.M. (2006) Groundwater Dynamics and Arsenic Mobilization in Bangladesh Assessed Using Noble Gases and Tritium. Environmental Science and Technology, 40, 243-250. https://doi.org/10.1021/es051284w

[33] Mook, W.G (2000) Introduction: Theory, Methods and Review. In: Environmental Isotopes in the Hydrological Cycle: Principles and Applications, Vol. 1, UNESCO and IAEA, Vienna.

[34] Falkenmark, M. and Chapman, T. (1989) Comparative Hydrology. UNESCO, Paris.

[35] Rozansky, K. and Fröhlich, K. (2001) Surface Water. In: Mook, W.G., Ed., Environmental Isotopes in the Hydrological Cycle, Vol. 3, UNESCO/IAEA, Paris, 72-74. 